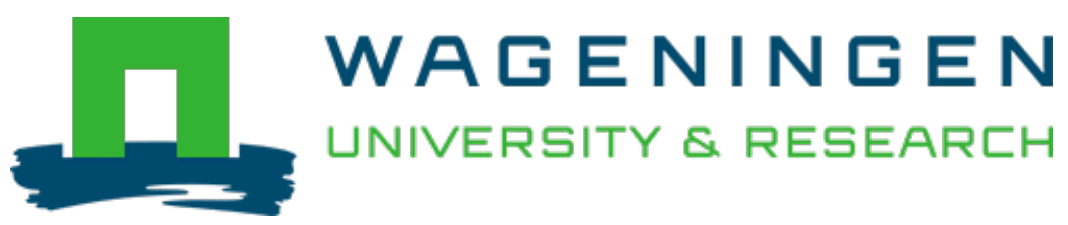

\title{
Agroecological peasant territories: resistance and existence in the struggle for emancipation in Brazil
}

The Journal of Peasant Studies

Berg, Leonardo; Goris, M.B.; Behagel, J.H.; Verschoor, G.; Turnhout, E. et al

https://doi.org/10.1080/03066150.2019.1683001

This article is made publicly available in the institutional repository of Wageningen University and Research, under the terms of article $25 \mathrm{fa}$ of the Dutch Copyright Act, also known as the Amendment Taverne. This has been done with explicit consent by the author.

Article 25 fa states that the author of a short scientific work funded either wholly or partially by Dutch public funds is entitled to make that work publicly available for no consideration following a reasonable period of time after the work was first published, provided that clear reference is made to the source of the first publication of the work.

This publication is distributed under The Association of Universities in the Netherlands (VSNU) 'Article $25 \mathrm{fa}$ implementation' project. In this project research outputs of researchers employed by Dutch Universities that comply with the legal requirements of Article $25 \mathrm{fa}$ of the Dutch Copyright Act are distributed online and free of cost or other barriers in institutional repositories. Research outputs are distributed six months after their first online publication in the original published version and with proper attribution to the source of the original publication.

You are permitted to download and use the publication for personal purposes. All rights remain with the author(s) and / or copyright owner(s) of this work. Any use of the publication or parts of it other than authorised under article $25 \mathrm{fa}$ of the Dutch Copyright act is prohibited. Wageningen University \& Research and the author(s) of this publication shall not be held responsible or liable for any damages resulting from your (re)use of this publication.

For questions regarding the public availability of this article please contact openscience.library@,wur.nl 


\title{
Agroecological peasant territories: resistance and existence in the struggle for emancipation in Brazil
}

\author{
Leonardo van den Berg, M.B. Goris, J.H. Behagel, G. Verschoor, E. Turnhout, \\ M.I.V. Botelho \& I. Silva Lopes
}

To cite this article: Leonardo van den Berg, M.B. Goris, J.H. Behagel, G. Verschoor, E. Turnhout, M.I.V. Botelho \& I. Silva Lopes (2019): Agroecological peasant territories: resistance and existence in the struggle for emancipation in Brazil, The Journal of Peasant Studies, DOI: 10.1080/03066150.2019.1683001

To link to this article: https://doi.org/10.1080/03066150.2019.1683001

册 Published online: 19 Dec 2019.

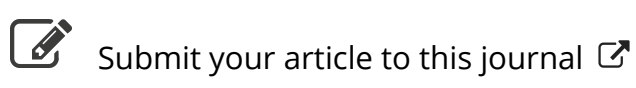

Џll Article views: 88

Q View related articles $₫$

View Crossmark data $\asymp$ 


\title{
Agroecological peasant territories: resistance and existence in the struggle for emancipation in Brazil
}

\author{
Leonardo van den Berg ${ }^{a, b, c}$, M.B. Goris ${ }^{a, b, c}$, J.H. Behagel ${ }^{a}$, G. Verschoor ${ }^{c}$, E. Turnhout ${ }^{a}$, \\ M.I.V. Botelho ${ }^{b}$ and I. Silva Lopes ${ }^{b}$ \\ ${ }^{\mathrm{a}}$ Forest and Nature Conservation Policy Group, Wageningen University, Wageningen, Netherlands;

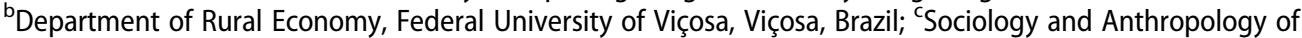 \\ Development Group, Wageningen University, Wageningen, Netherlands
}

\begin{abstract}
We explore peasant territories as an emancipatory alternative in the context of authoritarian populism and neo-liberalism by focusing on two agroecological peasant territories in Brazil. We argue that territories harbour socio-ecological, cultural-political and politico-institutional bases that engender different forms of resistance and existence. Peasant territories build and defend emancipatory alternatives by creating self-governed knowledge and production systems, by problematising and mobilising against exploitative relations, and by transforming parts of the state. We conclude that peasant territories provide a basis for emancipatory transformation. What is more, they can be considered as emancipatory alternatives in themselves.
\end{abstract}

\section{KEYWORDS}

Agri-food system transformation; food movements; peasant movements; upscaling agroecology

\section{Introduction}

In Brazil, the agribusiness sector is politically connected to neo-liberalism and supports and promotes food production that caters to global markets rather than local demands (Cunha 2017). This connection is part of a political trend that is connected to the globalisation of markets and is increasingly visible in countries across the world. Neo-liberalism fosters the commoditisation of agriculture and the insertion of peasants into global commodity markets, where they become subject to a 'race to the bottom' (Schneider and Niederle 2010; Camacho and Cubas 2011; Marsden 2012). Accordingly, it contributes to the economic marginalisation and social exclusion of local populations, including peasants and indigenous peoples (Bruff 2014; Cunha 2017).

Authoritarian populism ${ }^{1}$ is another political trend that threatens peasants' ways of doing and life (Bruff 2014; Thomas and Tufts 2016). It consists of a form of politics that present society as engaged in a struggle between 'the people' and a prejudiced other.

CONTACT Leonardo van den Berg leonardo.vandenberg@wur.nl; leonardo.vandenberg@gmail.com E Forest and Nature Conservation Policy Group, Wageningen University, 6708 PB, Wageningen, Netherlands; Sociology and Anthropology of Development Group, Wageningen University, $6700 \mathrm{EW}$, Wageningen, Netherlands

${ }^{1}$ Populism is also associated with (popular) movements and governments that have supported processes of democratization. Here, we follow Laclau and Mouffe (1985) and define populist movements and governments as those that seek to acquire popular support by building societal antagonisms, mechanisms of 'othering', and rhetoric devices. We thus argue that populist strategies may be employed both the political Left and the Right. 
Consequently, it uses the name of the people to justify interventions that are harmful to others, who often include peasants and indigenous peoples (Scoones et al. 2018). In Brazilian politics, the agribusiness lobby - which is now a controlling force in the Brazilian federal parliament - has actively pursued this form of politics (Andrade 2019). Since 2016, this political situation has ushered in austerity measures that dismantle pro-poor and pro-minority policies, including those specifically targeted at peasants (Andrade 2019).

Scoones et al. (2018) argue that emancipatory alternatives that allow people to be different and to do things differently are necessary to protect peasants and counter trends of neo-liberalism and authoritarian populism. Brazilian peasant movements provide an important base for emancipatory alternatives. These movements have historically constructed peasant territories: geographical and socio-material spaces that closely dovetail with peasant ways of doing and life (Escobar 2010; Camacho and Cubas 2011). Importantly, from the 1980s onwards many peasants have engaged with agroecology as not just a technical approach to agriculture and food production, but also as a political and social movement. In Brazil, this political and social movement champions a transformative epistemology based on principles of solidarity, reciprocity, horizontality and respect for nature (ANA 2014; Nyeleni Declaration 2015; Van den Berg, Hebinck, and Roep 2018a).

In the Zona da Mata region in Minas Gerais, peasants have recently protested against the neoliberal government of President Michel Temer (2016-2018) ${ }^{2}$ and concomitant austerity measures. As peasants put it, their territories are and have been a base of resistance against global markets which affect and try to control their ways of farming and of life. The impeachment of president Dilma Roussef in 2016 has triggered a new wave of resistance, reaffirming peasants' desire to do things differently and to construct alternative farming, education, innovation, market and other practices that strengthen their territories and promote emancipation.

Few studies explore how peasant territories foster emancipation. Many peasant, agroecology and food movement studies focus on farming practices, policies or social movements rather than peasant territories as the primary emancipatory agents (e.g. Altieri and Toledo 2011; Holt-Giménez and Shattuck 2011). Studies that do focus on peasant territories often conceptualise these as a product of explicit political conflict: as 'territories of resistance' that are shaped in reaction to 'territories of domination' (Fernandes 2008; Rosset and Martinez-Torres 2012), and tend to overlook how other, less oppositional needs and desires shape territorial resistance and encourage emancipation. How peasant territories engage with and support wider socio-political change therefore deserves further inquiry.

In this article, we explore peasant territories as an emancipatory alternative by focusing on two peasant territories in the municipalities of Araponga and Espera Feliz, in Minas Gerais, Brazil. We draw on data collected through participant observation, focus group

\footnotetext{
${ }^{2}$ The government of Michel Temer was succeeded by the current government of Jair Bolsonaro in 1-1-2019, which follows a similar economic course. While the current Bolsonaro government is much more explicit both in its authoritarianism (with inclusion of self-identified military veterans in the government) and populism (with frequent references to the political left and environmentalists as 'enemies of the country'), both trends were already visible in the Temer government. Moreover, both governments are critically supported by the same 'rural bench' (bancada ruralista), which represents the interest of agribusiness and global trade in Federal Parliament, for their base of power in government.
} 
meetings and interviews with peasant organisations (unions, associations, cooperatives, schools), informal groups (of peasant women, youth, church) and peasant farmers in the period 2016-2018 to provide a detailed account of how these territories have historically defended and advances peasant ways of doing.

In the next section. we elaborate on the concept of territories and the entwined linkages between resistance, existence, and emancipation. We then introduce the context of agrarian development in Brazil and the region of Zona da Mata in Minas Gerais, after which we present in-depth ethnographic accounts of two peasant territories. We show how peasants construct territorial practices that are autonomous and different from dominant practices and ideas. We then argue that territories defend and advance these practices by making strategic shifts under changing political trends and by taking control over production processes, fostering political mobilisation and transforming parts of the state. We conclude that peasant territories are both bases for the construction and defence of emancipatory alternatives as well emancipatory alternatives themselves.

\section{Territories: resistance, existence and emancipation}

\subsection{Peasant territories and emancipation}

Peasant emancipation lies in the creation of autonomy from hostile relations and in allowing and fostering the construction of different ways of knowing and doing and in creating horizontal engagements between these different ways. We understand peasant territories as geographical and socio-material spaces that closely dovetail with peasants' ways of doing and ways of life (Porto-Gonçalves 2006; Escobar 2010; Camacho and Cubas 2011). These peasant territories are dynamic entities and territorial change is a non-linear process. Accordingly, we emphasise heterogeneity, contradictions and complexity in our understanding of territory (Long 2001; Escobar 2010; Woods 2015). Specifically, we consider territories to be able to fulfil multiple functions that build on each other: they at once serve as socio-material basis for emancipatory action and they constitute emancipatory alternatives that peasants strive to create and maintain.

The socio-material basis for emancipatory action of peasant territories lies in how they defend and advance peasants' life and ways of doing. In particular, territorial development consists of a struggle for autonomy from hostile agents. Hostile agents include landlords, agri-business, extractive industries, and large corporations who struggle with peasants territories over land, food, markets, agricultural inputs and other resources, as well as over policies and ideas of how resources should be used, managed and distributed (Fernandes 2008; Escobar 2010; Camacho and Cubas 2011; Rosset and MartinezTorres 2012). Peasants create autonomy from these agents by developing particular ways of farming, (Van der Ploeg 2008), markets (Schneider), and securing rights to resources such as land (Borras, Fernandes 2008; Van den Berg, Hebinck, and Roep 2018a). Autonomy can be obtained in different ways. Land rights can for instance be obtained through the legal demarcation of geographical areas as 'indigenous' or 'peasant' land, by conquering land or by purchasing it (Fernandes 2008). The struggle for autonomy occurs at different levels. For example, efforts by peasant movements to ratify the United Nations declaration on the 'Rights of Peasants and Other People Working in Rural Areas' took place at the international level. 
Territorial development aims to constitute emancipatory alternatives through the construction of difference. As it proceeds, agents learn and create knowledge and practices by building alliances, distancing themselves from mainstream institutions, and experimenting with new practices (Wiskerke and Van der Ploeg 2004; Schneider and Niederle 2010). According to Escobar $(2010,48)$, territorial development may occur along the lines of dominant ideas of economy, individual, rationality, separation of nature and culture, mind and body and so forth, or it may imagine explicitly alternative constructions of the world from the perspective of difference. Difference need not be constructed in opposition to dominant knowledge and practices, but may also emerge from what existed prior to what was dominant (Porto-Gonçalves 2006), or from bodily affects that overflow dominant practices and representations (Haraway 1993).

\subsection{Resistance and existence}

Authoritarian populism and neoliberalism may threaten peasant territorial practices, including the autonomy and difference that they harbour. These threats manifest themselves through laws, policies, markets and other interventions that put peasants in a position in which they have to compete for, or where they become prone to the grabbing of, resources by banks, agri-businesses, the state and peers (Van der Ploeg 2008; Schneider and Niederle 2010; Scoones et al. 2018). Such threats may be countered through both active and direct, as well as passive and indirect struggles.

Emancipatory struggles do not only become manifest as a fight against threats, but also as a fight for a different way of life - a different way of doing things. Some authors (e.g. Porto-Gonçalves 2006; Daskalaki 2017; Sherwood, Arce, and Paredes 2017) propose to call this 'a fight for existence': a struggle against something or someone may thus be part of a larger struggle in favour of something else. In other words, peasant struggles can be a means to create room for something new. Struggles in support of something different often entail challenging dominant ideas and assumptions. Accordingly, we consider existence as an integral part of multiple forms of resistance.

We distinguish four forms of resistance: (1) overt resistance, (2) everyday resistance, (3) resistance of the third kind, and (4) rightful resistance. The first and most visible form of resistance is when agents come together around political ideas and engage in an 'overt' struggle, such as roadblocks, strikes, rebellions, demonstrations, and occupations (Wolf 1975). Overt resistance can be part of revolutionary expressions of class struggle (Paige 1975; Wolf 1975), as well as defensive responses to threats to peasants' livelihoods (Scott 1976). Agents that come together in overt struggles may also do this as part of a strategy for existence: they want to create space for something new. Vergara-Camus (2009) for example shows how peasant rebellions in Brazil and Mexico were employed as a political resource to counter neo-liberal authoritarianism and sustain pressure on authorities to allow acquisition of land and building of new livelihoods by peasants. Overt resistance can also be used to counter authoritarian populism and assert peasants and workers as 'the people' rather than prejudiced 'others'.

The second type of resistance is covert or everyday resistance, which occurs when agents seek to disassociate themselves from super-ordinates, such as landlords, employers or government officials, in the practice of everyday life (Scott 1987). This form of resistance is informal, subtle, indirect, and non-confrontational, including instances of foot-dragging, 
petty theft, or sabotage. Damage need not be material but may also be directed at symbolic elements that hold the relation with super-ordinates together (e.g. rumours, jokes about super-ordinates). The transformative potential of everyday resistance is found in the establishment of a supportive narrative that carries criticisms of prevailing political conditions; these may feed into other forms of resistance but may also cultivate existence and the desire for alternatives (Scott 1987; Malseed 2008; Kerkvliet 2009). The agroecology movement for instance creates a narrative that values peasants, quilombolas and indigenous peoples' way of doing while countering prejudices about race, gender, and rural people.

The third type is 'resistance of the third kind', which resides in production and distribution practices (Van der Ploeg 2007, 2008). Resistance of the third kind is realised by creating or tuning production and distribution practices - for example, machinery, fertilisers, or markets - in order to become more autonomous from neo-liberal markets, and to be governed by alternative values such as reciprocity or solidarity (Van der Ploeg 2007, 2008; Sabourin 2011; Van den Berg, Hebinck, and Roep 2018a). Peasants may do this by buying less and producing more of their own goods and by establishing their own processing plants, food markets, labour arrangements and/or credit schemes instead of relying on global markets (Schneider and Niederle 2010; Pahnke 2015; Van den Berg et al. 2018b). This type of resistance strongly builds on expressions of existence, in particular when it leads to new production and distribution practices.

The fourth type is 'rightful resistance' (O'Brien and Li 2006; O'Brien 2013). Whereas overt resistance openly challenges governmental authority, rightful resistance engages with government through negotiation. In doing so, rightful resistors strategically employ the ideas and commitments of the powerful to change policies or laws that will serve their own interests (O'Brien and Li 2006). Rightful resistors often use divisions within the state by for example collaborating with some government institutions to exert pressure on others. Rightful resistance has been employed both to defend vulnerable groups from threats such as privatisation and legal reforms and to advance existence and autonomy, for example through policies and laws that support alternative practices (O'Brien 2013) (Table 1).

\section{Social movements and the Brazilian state}

In Brazil, land and improved rights for rural workers have, for a long time, been the central concern for peasant movements and organisations (Fernandes, Welch, and Gonçalves 2012; Welch and Sauer 2015). The struggle for land and rights diminished when the military seized power in 1964 and peasant organisations were banned. The government pursued a project of agricultural modernisation and export-led growth and policies were directed at the scaling and mechanisation of large rural estates. As a result, many peasants were displaced from their land, because they had to make way for these projects, and many rural workers were replaced by machines (Meszaros 2000).

To support peasants, the Pastoral Land Commission (CPT) was founded in 1975 by the left wing of the Catholic Church (CPT 1997; Fernandes, Welch, and Gonçalves 2012). During the period of military control, only Church-based organisations were allowed to work with and organise the poor, enabling these organisations to secretly support the development of peasant movements (CPT 1997; Wolford 2010). At the time, considerable parts of the 
Table 1. Characteristics of different forms of resistance.

\begin{tabular}{|c|c|c|c|c|}
\hline & Agent(s) & Emergence & Resistance & Existence \\
\hline $\begin{array}{l}\text { Overt } \\
\text { resistance }\end{array}$ & $\begin{array}{l}\text { Peasants who } \\
\text { come together } \\
\text { around a social } \\
\text { demand }\end{array}$ & $\begin{array}{l}\text { Spontaneously from } \\
\text { informal networks } \\
\text { and/or formally } \\
\text { organised }\end{array}$ & $\begin{array}{l}\text { Confront powerful agents } \\
\text { and demand to stop } \\
\text { changes that damage } \\
\text { peasants }\end{array}$ & $\begin{array}{l}\text { Confront powerful agents } \\
\text { and demand recognition } \\
\text { and/or support of } \\
\text { difference }\end{array}$ \\
\hline $\begin{array}{l}\text { Everyday } \\
\text { resistance }\end{array}$ & $\begin{array}{l}\text { Peasants' } \\
\text { everyday } \\
\text { practices }\end{array}$ & $\begin{array}{l}\text { Spontaneously from } \\
\text { informal networks }\end{array}$ & $\begin{array}{l}\text { Damage everyday practices } \\
\text { at the cost of powerful } \\
\text { agents without } \\
\text { confronting them }\end{array}$ & $\begin{array}{l}\text { Nourish everyday practices } \\
\text { that allow for difference }\end{array}$ \\
\hline $\begin{array}{l}\text { Resistance of } \\
\text { the third } \\
\text { Kind }\end{array}$ & $\begin{array}{l}\text { Peasant } \\
\text { production and } \\
\text { distribution } \\
\text { practices }\end{array}$ & $\begin{array}{l}\text { Strategic orientation } \\
\text { towards autonomy }\end{array}$ & $\begin{array}{l}\text { Production and distribution } \\
\text { practices that minimise } \\
\text { dependency on powerful } \\
\text { agents }\end{array}$ & $\begin{array}{l}\text { Production and } \\
\text { distribution practices } \\
\text { that allow for difference }\end{array}$ \\
\hline $\begin{array}{l}\text { Rightful } \\
\text { resistance }\end{array}$ & $\begin{array}{l}\text { Peasant alliances } \\
\text { with powerful } \\
\text { agents and their } \\
\text { ideas }\end{array}$ & $\begin{array}{l}\text { Formally organised, } \\
\text { clearly defined } \\
\text { objectives }\end{array}$ & $\begin{array}{l}\text { Create alliances with } \\
\text { powerful agents to } \\
\text { negotiate or inhibit } \\
\text { institutional or policy } \\
\text { change from damaging } \\
\text { peasants }\end{array}$ & $\begin{array}{l}\text { Create alliances with } \\
\text { powerful agents to } \\
\text { negotiate for } \\
\text { institutional or policy } \\
\text { change that allows for } \\
\text { difference }\end{array}$ \\
\hline
\end{tabular}

Catholic Church in Brazil embraced Liberation theology, which is based on a materialist perspective of society and interprets the teachings of Jesus Christ in terms of liberation from unjust economic, political, and social conditions (Boff and Boff 1986). CPT's support for peasant movements ranged from mediating between peasants and government officials, to providing legal support to peasants entangled in disputes over and giving advice to peasants on nutrition and farming practices (CPT 1997). After the restoration to democracy in 1985, open struggles for land and rights for rural workers were once more possible and many new peasant movements and organisations arose. One of these organisations is the Brazilian landless workers movement (MST), which occupies abandoned land, demands its redistribution, and establishes new peasant territories (Stédile and Fernandes 1999; Wolford 2010). The MST aligned workers' dreams to live a free and autonomous life with movement leaders' wish for cultural change and revolution, which at times also generated tensions within the movement (see Loera 2006).

Another movement that emerged in the 1980s is that of the Base Ecclesial Communities (CEB): self-organised, autonomous groups that engage in politically oriented readings of the bible, using Liberation theology, with the purpose of improving their own conditions (Betto 1985; Boff and Boff 1986). The CEB's were set up by the Catholic Church and led by community members. With support from the CPT, the CEBs provided a basis for the foundation of new local rural workers' unions (STR). In many parts of Brazil, the CEB's and Liberation Theology questioned relations of patronage and dependency between sharecroppers and rural workers and landlords, giving voice to poor, silent and seemingly powerless populations (Stédile and Fernandes 1999; Comerford 2003), such as those described by Scheper-Hughes (1992) in the Brazilian Northeast. In this period, governments continued to almost exclusively invest in mechanised, chemical and export-led agriculture. This agri-business model of farming is also known as the Green Revolution and was later also promoted under family farmers.

In the 1990s, the focus of many peasant movements shifted from land reform and rights for rural workers to a struggle for an alternative rural development paradigm (Favareto 2006). New organisations included the Federation of Workers in Family Farming 
(FETRAF) and the Movement of Small Farmers (MPA). These movements began to criticise neo-liberal development and the agri-business model of farming and constructed alternatives based on principles of sustainable development, solidarity, and social and political democracy (Silva, Dias, and Silva 2014). These and other peasant organisations, including the MST, embraced agroecology as an alternative to the agri-business model of farming and formed alliances with other organisations working with agroecology - including academic and research institutions and NGOs (ANA 2014). In 2002, these organisations formally united in the National Articulation for Agroecology (ANA). Older movements such as the Movement of Rural Women also re-invented themselves as a network including multiple, autonomous movements (Rubin and Sokoloff-Rubin 2013). In 2003, the Workers Party (PT) rose to power and, under the pressure of peasant and agroecology movements, new policies and laws supporting peasants and other marginalised groups were established. These included credit programmes to access land, funds for rural education, and support for the establishment of institutional food markets (ANA 2014; da Costa et al. 2017). While these were positive political changes for peasant and agroecology movements, at the same time a powerful elite constituted by large plantation holders, transnational agri-business corporations and local rural elite - represented by the 'rural bench' in Federal Parliament - did not completely lose power. In different areas of Brazil, it even expanded its control over land and other resources, often at the expense of more vulnerable populations of rural workers, smallholder farms, indigenous peoples, quilombolas, mineworkers and rubber-tappers (Zimerman 2010, 2016).

Policies and laws supporting peasants ended in the 2010s when right-wing populist opposition movements, nourished by right-wing Brazilian media empires, rose against the PT government (Pimentel 2015; Firmino 2017; Vieira 2017). This culminated in the impeachment of president Dilma Rouseff in August 2016. Under the newly inaugurated president, Michel Temer (2016-2018), austerity measures were put into place. Policies supporting peasants, indigenous peoples, and other minorities have been and continue to be dismantled while support for agri-business is on the increase (Cunha 2017).

The history of peasant movements in Brazil is intertwined with the development of peasant territories in Araponga and Espera Feliz. In the 1980s, hundreds of CEB groups were established in both Araponga and Espera Feliz. CEB members from both territories later approached the CPT to establish an STR in Espera Feliz in 1986 and one in Araponga in 1989. The initial objective of the STR was to protect rural workers and sharecroppers from encroachment by landlords. In Araponga, this focus shifted to land acquisition when the Land Conquest Movement arose in 1989.

In the 1990s, both territories also focused on alternative rural development and agroecology. The peasant unions from both municipalities became part of large peasant federations, FETRAF and FETAEMG, who in turn teamed up with the Centre of Alternative Technologies (CTA) and the Federal University of Viçosa, thus becoming part of ANA. New alliances and ideas led to the establishment of peasant associations, credit cooperatives, novel farming practices and local markets. The federal and state governments were effectively pressured to implement policies that helped establish land credit programmes, institutional markets and peasants' schools. Today, the new government is dismantling these same policies.

Peasant territories responded to neo-liberal authoritarianism by shifting between different types of resistance and existence. From 2003 to 2016, and under the aegis of 
the Workers Party governments, many peasant movements directed their efforts at rightful resistance - negotiating and pushing through new policies and laws. This allowed them to build new territorial practices and expand their territorial bases. When president Dilma Rouseff (Workers Party) was impeached in 2016 and austerity reforms were put in place, efforts shifted to more overt forms of resistance aimed at countering these reforms. At the same time, these protests also continuously questioned the legitimacy of the new government. Despite the dismantling of many policies that supported peasants, rightful resistance efforts were not in vain as many territorial practices were to some degree autonomous from political change and continue to exist today. At present, new forms of resistance and existence are beginning to emerge.

\section{Resistance in the Zona da Mata, Minas Gerais}

\subsection{Overt resistance}

When the Michel Temer government seized power from 2016 to 2018 after the impeachment of president Dilma Rouseff, a wave of protests took place in Brazil. The most visible protests were those opposing social welfare and labour reforms (as proposed by the Proposta de Emenda Constitucional 287 or PEC 287). PEC 287 proposes a reform of the pension system, replacing the right to pension after 35 years of work for men and 30 years for women, with a minimum pension age of 65 years old for both men and women. While pensions are funded by income - and other taxes - the reform requires peasants to pay an additional monthly contribution per household member. Peasant movements argue that this is unfair because they are already putting more into the pension system than that they get out of it. They also argue that peasants and workers will be hit hardest by these reforms because they start working at an early age and because their professions demand heavy labour. Peasant women who have a double workload (they work on the farm and at home) will be hit even harder.

Peasants' organisations, federations and confederations, including the Federação dos Trabalhadores e Trabalhadoras na Agricultura Familiar (FETRAF), Federação Trabalhadores Agricultura do Estado de Minas Gerais (FETAEMG), Confederação Nacional dos Trabalhadores na Agricultura (CONTAG) and the Movimento dos Trabalhadores Rurais Sem Terra (MST) as well as other workers' organisations and social movements, joined hands to mobilise people and organise protests against PEC 287. Peasants and peasant organisations in Araponga and in Espera Feliz were involved in some of these protests, including a large protest in Brasilía in December 2016 and the first nationwide general strike in 23 years, in June 2017.

We voted for President Dilma [...] but he [Michel Temer] took our vote. So we said: 'we have to do something'. The fire was burning in ours veins: 'let's to go to the street and demonstrate'. (José, Leader Peasant Youth Group in Araponga)

Another large anti-PEC 287 demonstration was the 'For the life of Women! Against Welfare and Labour Reforms' demonstration in Belo Horizonte on International Women's Day in March 2017. For the women, the demonstration was not a conservative response to, or a fight against, PEC 287. Women also mobilised because the Temer government (20162018) signified a regression in what they accomplished in their fight for existence as women within the state, including rights and recognition for their work. 
The fact that we are women doesn't mean that we don't have rights. So we are defending our rights. - Participant of the 'For the life of Women!' (Maria, Demonstration Participant from Espera Feliz)

Overt resistance against PEC 287 was also organised in the vicinity of Espera Feliz and Araponga on the 15th of March 2017 by youth and peasant organisations who blocked two highways (BR116 and BR265).

Overt resistance was also directed against other government reforms. On the 6th of December 2017, the Education Department of the Federal University of Viçosa (UFV) was occupied. Students, including peasants from Araponga and Espera Feliz, as well as university staff protested against severe budget cuts in the 'Education for and by the Countryside' programme as well as against 'Education without party' reforms. The former funds Licena, a university study that is designed to be accessible to peasants and is based on pedagogies that value peasants' practices and experiential knowledge. 'Education without a party' is a law that aims to limit political and societal discussions at high schools, for example by banning subjects such as philosophy and sociology. Peasants' main concern with the law and budget cuts is that they threaten difference and diversity by restricting peasants' freedom of expression and devaluing peasant knowledge.

They are creating a type of education in which you have no voice; you are the receiver of what the teacher teaches. (Fernanda, Student Lycena from Espera Feliz)

Some protests against the Temer government were part of events that seek to forge new and strengthen existing collaborations and celebrate diversity and difference. The Troca de Saberes (Exchange of Knowledges), a yearly event at the Federal University of Viçosa, aims to bring together citizens, students, researchers and peasants from neighbouring territories. Next to a protest against the government's reforms, the event hosted workshops on agroecological practices, presentations by peasant and Indigenous people and stalls depicting collaborative efforts between peasants and researchers. At the fourth National Agroecology Encounter (IV ENA) held at the beginning of June 2018 in Belo Horizonte, protests were also held alongside sessions where delegates from different territories shared and celebrated their struggles and experiences with agroecology and discussed collaborations and plans to deal with the current challenges. Preceding the IV ENA, regional encounters and protests were organised for the Zona da Mata region in Viçosa.

Next to a struggle for existence and against reforms, protests and the events that they were sometimes part of were sites of encounters where difference was articulated and where collaborations for existence and resistance were cultivated, forged or strengthened:

At the manifestations we are all united. We get to know each other, other groups. (Silvia, Member of the Raízes da Mata women's group in Espera Feliz)

\subsection{Everyday resistance}

An important form of everyday resistance in Araponga and Espera Feliz is found in the reflection groups of the Base Ecclesial Communities (CEB), which were informed by Liberation Theology and established throughout the whole of Brazil (see also chapter 4). During CEB's meeting members began to criticise the idea of sharecropping: they had to do all the work while receiving less than half of the harvest, were forced to work when it was raining or when they were sick, and had little choice over what, when, and how to plant. Through 
these encounters and discussions at the CEB's the idea of sharecropping changed from being seen as 'natural' to something that is unjust.

In a way she [the CEB's] awakens the oppressed. (Fernando, Board Rural Workers Union Araponga)

This new view led peasants in Araponga and Espera Feliz to organise themselves in what became the municipal Rural Workers Unions (STR), which offered legal protection to sharecroppers and rural workers from landlords.

In Araponga, the topic of sharecropping led to discussions about the unequal distribution of land. True justice, peasants concluded, could only be attained if they owned land. This wish for land also arose out of peasants' desire for a different existence; a life where peasants could decide when, what, and how to farm themselves. Land ownership was seen as the only way to become completely free from landlords. These discussions led peasants to form collaborations that would purchase land in groups. This became known as the Joint Land Conquest Movement.

The necessity arose for us to discover a way to obtain land. The problem was that we were poor, we didn't have any money. [...] We had to think of a different strategy to conquer land. (Donival, Board STR Araponga)

In the two decades that followed CEB's participants also challenged existing farming, market and education practices, forged agroecological alternatives and founded new organisations (see also below).

The union is CEB, the CTA is CEB, the EFA is CEB. All these organizations were born from her. [...] She pushed people to think and to create these institutions. [...] She made the movement. (Niuton, Coordinator Land Conquest Movement)

Beyond the reflection groups, the CEB's also came to mean what some peasants in Araponga refer to as 'life': loose encounters that cultivate the expression and articulation of difference and existence.

She [the CEBs] is the mother because she is patient with you, she gives you warmth, she feeds you, she takes care of you. The father [the union] gives direction, he imposes order. But the CEB's is very caring. [...] She is a force that is more inside people, that says: go, you can do it. You can do it, go. [...]. (Niuton, Coordinator Land Conquest Movement)

The CEB's doesn't have this thing of being Catholic or Christian. She has an awakening role. (Joana, Board STR Espera Feliz)

Despite their achievements, the number of CEB's groups has diminished in both municipalities. In the 1980s, Espera Feliz counted over 400 reflection groups, in 2017 there were 267. The activity of groups has also diminished. According to representatives of the STR in Araponga and Espera Feliz reasons for this include the Vatican's rejection of Liberation Theology, a shift in activity to formal peasant organisations which were no longer illegal after the dictatorship in 1985, criticism of CEB's members about the workings of the Catholic Church, increased dependency on public policies, and division within the CEB's regarding issues related to agro-toxin use. However, with a hostile government in power, peasants' unions in both Araponga and Espera Feliz have re-directed their hopes and efforts in the CEB's. 
The CEB's are returning and becoming stronger because with this government people came back to themselves, to reality. (Joana, Board STR Espera Feliz)

Apart from the CEB's, everyday resistance is also present in self-organised women groups, of which various exist in Espera Feliz. At these meetings, women challenge the idea that the use of pesticides is necessary to have a decent income and life. Instead, pesticides have come to be seen as damaging their health and the local environment and tied to a system that exploits peasants. Women also challenged the idea that coffee production is a male domain, as it significantly relies on the labour of their women and children.

Like the CEB's, the women groups also nourish difference and existence. They do this by organising farm visits, recipe exchanges, workshops, food tastings, meetings and conversations. At these meeting, new ideas form and new agroecological practices emerge around forgotten plants, vegetable gardens, handicrafts, medicinal plants and beauty products, amongst others.

By fostering own production instead of buying industrialised foods such as pasta, soda, and instant juices, everyday existence feeds into resistance of the third kind. Within the group women are stimulated to express themselves and develop argumentation, mobilisation and organisation skills that are seen as important for peasant movement work, thereby feeding into rightful resistance.

When I came in here, I had no courage to speak to people. I did not have the guts to pick up things. But nowadays I am the secretary of the group. So I think, the group of women help us a lot to raise self-esteem. (Josefina, Board Raízes da Terra Womens' Group)

The government austerity measures for instance have motivated women groups to work on becoming more self-sufficient in terms of food, medications and so on (see section on 'resistance of the third kind'). Everyday resistance and existence were also found to feed into rightful and overt resistance as women were stimulated to join demonstrations, the board or working groups of the STR and other peasant and women organisations.

\subsection{Resistance of the third kind}

Resistance of the third kind can be found in several farming practices, many of which were constructed in response to government policies and practices that promote agribusiness ways of doing. These agents pressured peasants to use chemical fertilisers, to specialise in the production of coffee, and to adopt mono-cropping. They promised that these practices would give peasants freedom and wealth. The production of food crops was discouraged. It was said that food crops could better be bought in the supermarket.

Peasants, however, were not always able to produce enough coffee to pay back the investments they had made in farm inputs and buy food, especially when the price of chemical fertilisers and food in the supermarkets began to increase. Agri-business practices were moreover causing land degradation which led to yield declines.

I was so busy with producing coffee that I could not take care of my mother when she became sick. (João, Arapongan peasant)

When peasants realised that agri-business practices degraded their natural resource base and did not bring the freedom they envisaged, they began to challenge these practices. Discussions took place at the CEB's, peasant organisations and informal groups which 
led peasants to collaborate with the CTA and the Federal University of Viçosa (UFV) and devise agroecological practices that reduced land degradation and farm dependency on coffee markets. These collaborations led to new initiatives including farmer-led experimentation, on-farm experiments, peasant-to-peasant exchanges and other gatherings where problems and progress were reflected upon.

In Araponga coffee agroforests were developed with trees that can supply nutrients to the coffee, like Mycorrhiza-hosting trees that can adsorb phosphorus that is tightly bound to the soil, leguminous trees that can capture nitrogen from the air, or deeprooting trees that can take up nutrients at greater depths (Cardoso et al. 2001; CTA 2005). In both municipalities practices to protect and regenerate soils (e.g. tree planting, green manuring, cover cropping, and selective weeding) arose. When these practices were in place in the 1990s joint experimentation and exchanges amongst peasants and between peasants and researchers continued. These new practices strengthened peasants' resource base.

New, reinvented and revived food practices also emerged from peasants encounters and collaborations. More and a higher diversity of food crops were cultivated including a large variety of crops, vegetables, fruits and medicinal plants. Animals were also held, including chickens, pigs, cattle and goats. Trees were planted in agroforestry systems for their fruits and wood. Foods began to be processed by peasants themselves - both in a collectively-owned processing plant and by a municipal peasant cooperative. Cassava and maize, for example, were processed into flower; pig fat and avocados into soap; sugarcane into sugar; milk into cheese; and fruits into jams and juices.

Peasants continued to produce coffee and engage in commodity markets to obtain money. They argued that they did this to be able to go to the doctor or dentist when needed, send their children to university or simply be able to go out or have a vacation.

Agroecological practices were not only used to reduce dependency on commodity markets but also for existence (Botelho, Cardoso, and Otsuki 2016; Van den Berg et al. 2018b). Many peasants wanted to create a type of farming that allowed them to live and work according to values that differed from agri-business ones. They wanted more freedom to decide when and how to work, to farm with more respect for nature, and for their farm to be a pleasant and healthy environment for their family to live and work in. Foods were not only grown to avoid the supermarket but also because peasants valued the taste of their own varieties. Some trees were kept because they had beautiful flowers or because they offered shade while working the field. Some products such as cheese were produced as gifts. Sugarcane was produced to share with fellow peasants who helped out with the harvest.

Resistance of the third kind was found not only in farming practices but also in practices through which peasants acquired land and credit for land. The Land Conquest Movement, for example, functions as an alternative land and credit market in Araponga (Campos 2014; Van den Berg, Hebinck, and Roep 2018a). Strict conditions and high interest rates make it unfavourable for peasants to acquire credit from banks and land is often expensive and sold in large tracts. With the Land Acquisition Movement peasants formed groups, pooled their financial resources and collectively bought land. The Land Conquest Movement also tried to ensure that land that peasants wanted to sell was offered to fellow peasants, so that land remained within the peasant territory. 
With the land acquisition movement the people themselves do everything. They pay for the land, they build their own house, plant their fields [...] with their own resources. (Niuton, Coordinator Land Conquest Movement)

The land conquest movement is also an expression of existence. While it enables peasants to access credit outside of, and keeps land from entering, neo-liberal markets, the movement is also seen as a project to create an agriculture that is based on values that respect the land, animals, and neighbours. These values are also reflected in the 'ten commandments of land conquest' drafted in 1995, which are a set of principles such as 'recover and preserve the soil', 'use leguminous species', 'visit your neighbours farm', 'recover and preserve the soil', 'take care of animals' (CTA-ZM 2002, 26).

Resistance of the third kind was also found in alternative food markets that made peasants less dependent on the coffee market, allowing direct sales to consumers. In both Espera Feliz and Araponga peasants founded a cooperative through which they run a peasants' shop and an open peasants' market. The shop and the open market sell fruits, vegetables, cassava, coffee, beans, maize, maize flower, cassava flower, sugar, honey, syrup, and other products directly to consumers.

When you are able to get things directly from producer to consumer, both gain. Because you can sell for more while the consumer pays less. Unfortunately, it is usually the middlemen who take the largest share. (Edimar, Arapongan Peasant)

To support these markets, the cooperative in Espera Feliz established processing plants that, for example, grind coffee into powder or package maize flower and beans. Next to selling within the municipality, the cooperatives in Araponga and Espera Feliz collaborate with the CTA and the UFV to establish the Rede Raízes da Mata, a network that links peasant cooperatives to open markets and shops in Viçosa. The cooperative in Espera Feliz also collaborates with consumer cooperatives in the major cities of Brasília, Rio de Janeiro, Belo Horizonte, and São Paulo. Next to consumer markets the cooperatives in Araponga and Espera Feliz have also created an institutional market through which they provide food for school lunches. This is made possible by a government law (see the next section).

\subsection{Rightful resistance}

Rightful resistance is largely found in practices through which peasants negotiate changes in government policies and laws and make claim to access these and other policies and laws. Through their involvement in the large peasant federations FETAEMG and FETRAF, the STR of Araponga and Espera Feliz were able to do so.

It was because of the struggle by movements, not only by the one in Espera Feliz, that we conquered public policies to access land, markets and dignified housing. (Joana, Board STR Espera Feliz)

One of these policies is the Land Credit Policy (Crédito Fundiário) which provides loans for farmers to buy land at low interest rates. Later, the Housing Policy (Política de Habilitação), which provides finance for farmers to build a house on the purchased land, was implemented. The STR in both municipalities mediated access to these policies. Becoming recipients of these policies is considered to be only one part of rightful resistance. Claiming the benefits these policies bring often meant the STR had to go dodge complex 
bureaucratic hurdles (e.g. produce a whole range of documents peasants often did not have such as land titles, identity cards or producer's cards) and pressure government representatives in Belo Horizonte or Brasília.

With the impeachment of president Dilma Rousseff in 2016 the land credit and housing policies were frozen until further notice. The STR in both municipalities are currently negotiating with government officials to accept the applications for credit that were made before the policy was frozen.

We fought nine years to get a proposal for the Land Policy approved to settle 38 families [...] which are pending for two years, four years. (Joana, Board STR Espera Feliz)

Peasants have little hope that the policies will continue. Nevertheless, peasant territories have already been able to acquire large tracts of land as a result of them. In Espera Feliz, 100 families acquired land and 80 people a house. They also established a new settlement: Assentamento Padre Jésus. In Araponga, land acquisition continues through the land conquest movement (see section on 'resistance of the third kind'):

The land conquest movement slowed down after the Land Credit Policy [...] But today people are going back to the old model [the Land Conquest Movement]. (Niuton, Coordinator Land Conquest Movement)

Rightful resistance can also be found in the Food Acquisition Programme (PAA). The PAA finances the acquisition of food stocks for social welfare organisations. In Araponga and Espera Feliz the programme is coordinated and mediated by peasant cooperatives. Like the Land Credit Policy, the PAA faces continuous bureaucratic hurdles. These include getting proposals approved, getting all institutions registered for the programme, negotiating with individual farmers about the amounts they will deliver, and making sales reports of every delivery. According to a peasant representative in Espera Feliz, just making the report is almost a day's work. The food acquisition programme has also been frozen. However, peasant cooperatives in Araponga and Espera Feliz are confident that what they build (through resistance of the third kind) will stay.

We established other markets. We did not only focus on public policies. [...] Because if the public policy stops, the doors would close. [...] These markets are not affected by government. They give the cooperative independence. (Joana, Board STR Espera Feliz)

Rightful resistance is evident as well in the National School Feeding Programme (PNAE). PNAE is based on a law that dictates that at least $30 \%$ of the ingredients in school meals from public schools should be produced by family farms. Like with the PAA, the peasant cooperatives coordinate this programme by maintaining contact with the different schools and farmers and synchronising supply and demand for a wide range of foods. PNAE is currently still in place. By organising continuous engagement between schools and peasants, it feeds into resistance of the third kind (see above).

Rightful resistance is also present in the continuous claims that the peasant high school Escola Família Agrícola (EFA-Puris) has to make to access the Bolsa Aluno, the Fund for Rural Education and other subsidies on which the school depends. Subsidies from the Fund for Rural Education have been cut by 50\% between 2015 and 2017 and are planned to be cut by another $86.1 \%$ in 2018 (Intini 2016). EFA-Puris has to apply for funding every year and on several occasions funds were not transferred, resulting in 
time-consuming negotiations with government officials. In a few cases negotiations failed and the school resorted to more overt forms of resistance, including a protest in Belo Horizonte and a petition, to obtain financial support.

The policies that peasant movements have negotiated, and have laid claims on, are also expressions of existence. Land is not only acquired for the sake of ownership, it is also 'a dream', a basis to establish a different way of farming and a different way of life.

Acquiring land is not acquiring land to simply have land [...] Because with land the family will live better, will be able to produce without using pesticides. Sometimes farmers don't have this independence where they live. Sometimes they are obliged to do things they are told to do because they don't own the land. (Joana, Board STR Espera Feliz)

A farmer without land is like a bird without wings. It knows that it cannot fly. (Donival, Board STR Araponga)

The markets created through the PAA and PNAE also support peasants in their struggle for a different type of life and farming, for instance by enabling them to combine farm diversification with sales of multiple products.

The EFA-Puris school seeks not only to offer access to education but also to construct a different type of education - one that values peasants' knowledge, experiences, and practices. This is done by organising farm excursions, talks by farmers, peasants' reflections on the work they carry out on their farms, and applications of the curriculum to farm practices (e.g. making soap during chemistry lessons and making effective micro-organism mixtures during biology). Much of the educational curriculum teaches students how to become less dependent on external knowledge and farm inputs, thereby feeding into resistance of the third kind. The school also teaches the history of their territory and its people - many of who are descendants from an Indigenous group called the Puri.

The Puri for us has two meanings: love for the land and the struggle for freedom. So you are free, you walk with your own legs, walk with your head up. You will not be anyone's employee.

(Fransisca, Coordinator Rural High School Araponga)

Overall, government austerity measures have had large impacts on the practices and prospects of rightful resistance. However, the STR's in Araponga and Espera Feliz trust that their territories have the capacity to deal with this.

There is a lot of work that we do that started before this government. [...] How did we do things before? The CEB's, the base work. (Joana, STR Espera Feliz)

'The persecution of the government is awakening the memory of the people. The people are waking up, and feel the need to unite and organise themselves. (Donival, STR, Araponga)

\section{Discussion: peasant territories as sites of and bases for resistance and emancipation}

\subsection{Peasant territories as sites of resistance}

Peasant territories in the Zona da Mata engendered different forms of resistance and existence to defend and advance peasant ways of doing and life in the face of political trends of neo-liberalism and authoritarian populism. In the literature on peasant territories, it is argued that peasant territories continuously confront, and enter into conflict with, 
agents that promote neo-liberalism such as governments, landlords and agri-business, because they threaten non-commodity relations that are seen to constitute the territory (Fernandes 2008; Camacho and Cubas 2011). While such conflicts are also present in the Zona da Mata, neo-liberal threats are also addressed through other, less confrontational means, including 'resistance of the third kind' and 'rightful resistance'.

Through resistance of the third kind, which includes the production of own inputs and food and the construction of nested markets, peasant territories reduced their dependency on some, and completely circumvented other, commodity markets, thereby significantly reducing pressures that draw peasants to a 'race to the bottom' (cf. Marsden 2012). Through rightful resistance, peasant territories moreover employ the government's own rhetoric on rural development and sustainability to negotiate for laws, agricultural extension, policies and rights that serve to advance peasants' ways of doing and life, such as the National School Feeding Policy and the Land Credit Policy. Rightful resistance was particularly employed under the Worker Party's government (2003-2016), which although mainly supporting agri-business, was more open to peasant and agroecological movements.

Escobar (2010) argues that in Latin America, the prejudiced 'other' of authoritarian populism has, since colonial times, been portrayed as non-modern groups such as black, peasant, women and indigenous people. Still, the central depiction of modernity as a defining feature of 'the people' is a more recent development. In Brazil, this arguably started with protests against the Rouseff's Workers Party government in 2015, where protestors claimed that left wing parties and the groups they support act against and rob 'the people' (Firmino 2017). The depiction of the people as modern and superior opposed to others as non-modern and backwards is expected to reach new extremes under Jair Bolsonaro's current government (2019-2022), which promotes the rhetoric that peasants, landless and indigenous people, environmentalists, social scientists, feminists, etc., act against the progress of the Brazilian people. In Brazil, moreover, this authoritarian populism goes together with neo-liberalism: the insertion of people in commodity markets is depicted as a defining feature of being modern.

To deal with threats of being excluded, marginalised or displaced it has been argued that networks that reassert and defend difference, and that promote horizontal dialogue between different knowledges, must be created (Porto-Gonçalves 2006; de Sousa Santos 2009; Escobar 2010). In the Zona da Mata, threats posed by authoritarian populism come from and are defended at both the local and the national level. At the local level, agents such as shopkeepers, municipal authorities, and pesticide salesmen spread the rhetoric that modern farmers, which include agri-businesses, plantations and entrepreneurial family farms, are superior to peasant farmers. They thereby create shame among peasants and tensions between them and neighbouring modern family farmers, pressuring them to modernise or migrate to the city. These threats are addressed through everyday resistance, which is found in spaces where peasants and their allies discuss and politicise modern agricultural practices. This includes the creation of counter narratives that depict the negative effects of modern farming on human health, the quality of products, the environment and on peasants' freedom, and that champion peasant and agroecological ways of doing. These spaces can be seen to constitute and nourish the formation of networks of difference that advance peasant narratives and where innovations that support peasants ways of doing and life are developed. 
At the national level, austerity measures implemented by the government of Michel Temer (2016-2018) threatened to dismantle policies and laws, including Education for and by the Countryside, the Land Credit Policy and the Food Acquisition Programme, that support peasants' territorial education, market and land acquisition practices. To address these threats overt resistance was employed, which mobilised peasants and linked them to peasant organisations throughout Brazil and to movements of rural and urban workers, quilombolas, indigenous peoples, landless farmers, environmentalists, feminists and other movements, in a mass protests against government reforms. While these protests did not stop the reforms, they did create and strengthen networks that affirm difference.

\subsection{Peasant territories as bases for emancipation}

Territorial development, as the unfolding of autonomy and difference, was found to be related to three pathways of emancipation. The first pathway lies in the farm labour and production process (Chayanov 1966; Van der Ploeg 2008, 2017). Several scholars (e.g. Toledo 1990; Chayanov 1991; Van der Ploeg 2008; Pahnke 2015) argue that peasant emancipation is fostered through the creation of production, processing and distribution systems that are autonomous from hostile relations such as landlords and commodity markets. Such systems are shaped according to peasants' own knowledge, values and aspirations and reduce peasant dependency on commodity markets, while not breaking the relations with commodity markets entirely. The latter still enable peasants to obtain financial resources to participate in societal activities such as go to university or a hospital without being drawn in a 'race to the bottom' (Van der Ploeg 2017). Peasant territories in the Zona da Mata harbour a socio-ecological base constituted by horizontal relationships between peasant, nature, the community and militants from peasant and agroecology movements, which, through resistance of the third kind, are drawn in different constellations to form production and distribution systems that are autonomous and attuned to values of cooperation, reciprocity, freedom, trust, friendship, and respect for nature. Emancipation was not only sought in production and distribution but also in the creation of self-governed education, innovation and land distribution systems.

The second pathway is found in the formation of political subjects and popular movements (Gramsci 1971; Laclau and Mouffe 1985). For Gramsci (1971), people become political subjects when they come to recognise and valorise themselves as protagonists and form a collective identity capable of transformation. A pathway to emancipatory alternatives then lies in the articulation of shared symbols or social demands that explicitly oppose dominant ideas, to create a popular movement that cuts across classes. In the Zona da Mata, social encounters of peasants in community groups, peasant schools and union gatherings can be seen to constitute a cultural-political base where, through everyday and overt resistance, peasants become political subjects. In these encounters, popular movements are moreover created by problematising everyday relations with landlords and agri-business and by articulating social demands that oppose agri-business together with researchers, citizens and activists. Finally, the politico-cultural base engendered articulations not only based on opposition to dominant agents and ideas, but also based on affects that overflow or pre-exist dominant categories.

A third pathway of emancipation lies within the state. Fox (2007), for example, argues that the pathway to emancipation lies in deepening engagements between the state and 
civil society. These engagements target state's institutional infrastructure through a politics of representation and accountability (Ribot 2013). This pathway resonates with the processes we described above as rightful resistance: In the Zona da Mata relations between peasant unions, cooperatives, federations, confederations, and agroecology organisations and the state formed a politico-institutional base that enabled peasant territories to engage with and transform the state. The relations, skills, and materials harboured by the politico-institutional base enabled policies and laws to be altered and new state-civil society mechanisms to be introduced; which, in turn, have led to peasant land acquisition and a better distribution of resources within peasant territories.

\section{Conclusion}

Peasant territories engender different forms of resistance and existence to defend and advance peasant ways of doing and life, particularly in the face of neo-liberalism and authoritarian populism. In the Zona da Mata threats against neo-liberalism are addressed by employing resistance of the third kind, which involves the production of own inputs and food and the construction of nested markets, to reduce dependency on commodity markets. Also, rightful resistance is employed to negotiate for policies that support these practices. Threats against authoritarian populism are addressed through everyday resistance and overt resistance, which challenge relations and narratives that depict peasants as inferior and which create narratives and networks that promote difference.

The significance of peasant territories for emancipatory alternatives is twofold. First, peasant territories contain a socio-ecological, cultural-political and politico-institutional base that harbours and nourishes a pool of horizontal relations between nature and people, natural resources, affects, skills, capacities and ideas. These relations have the potential to combine in constellations that foster emancipation by engendering different forms of resistance and existence, fostering people to problematise and mobilise against exploitative relations and transforming parts of the state.

Second, the peasant territory is an emancipatory alternative itself. Peasant territories are constituted by alternative, autonomous and self-governed farming, educational, market exchange, innovation, land distribution and other territorial practices. On the one hand, these territorial practices defend peasants from destructive political trends and create autonomy from dominant agents and ideas. On the other hand, these territorial practices operate according to peasants' own wishes and values such as that of cooperation, reciprocity, freedom, trust, friendship, and respect for nature, in contrast to those wishes and values expressed by proponents of neo-liberalism and authoritarian populism.

\section{Acknowledgements}

The authors would like to thank Wendy Wolford, Jun Borras, Paul Hebinck and the two anonymous reviewers for their comments. Also, our gratitude goes to the farmers and militants of the agroecology and peasant movements in the Zona da Mata who have helped shape this paper.

\section{Disclosure statement}

No potential conflict of interest was reported by the authors. 


\section{References}

Altieri, M. A., and V. M. Toledo. 2011. "The Agroecological Revolution in Latin America: Rescuing Nature, Ensuring Food Sovereignty and Empowering Peasants." Journal of Peasant Studies 38 (3): 587-612.

ANA. 2014. Agroecologia, desenvolvimento territorial e politicas publicas. Rio de Janeiro: ANA/FASE.

Andrade, D. 2019. Populism from Above and Below: Agriculture and the Political Ambiguities of the Workers' Party in Brazil (Vol. 83). ERPI Working Paper Series.

Betto, F. 1985. O que é Comunidade Eclesial de Base. São Paulo: Editora Brasiliense.

Boff, L., and C. Boff. 1986. Como Fazer Teologia da Libertação. Petropolis: Editora Vozes.

Botelho, M. I., I. M. Cardoso, and K. Otsuki. 2016. "I Made a Pact with God, with Nature and with Myself': Exploring Deep Agroecology." Agroecology and Sustainable Food Systems 40 (2): 116-131.

Bruff, I. 2014. "The Rise of Authoritarian Neoliberalism." Rethinking Marxism: A Journal of Economics, Culture \& Society 26 (1): 113-129.

Camacho, R. S., and T. E. A. Cubas. 2011. "A recriação dos territórios camponeses por meio da produção de alimentos e energia: A experiência do MPA em Frederico Westphalen-RS." Agrária 15: 4-44.

Campos, A. 2014. "Redes sociais, organizaçoes e politicas publicas: interfaces na agricultura do municipio de Araponga, Zona da Mata de Minas Gerais." PhD diss., Federal University of Rio de Janeiro.

Cardoso, I. M., I. Guijt, F. S. Franco, A. F. Carvalho, and N. P. S. Ferreira. 2001. "Continual Learning for Agroforestry System Design: University, NGO and Farmer Partnerships in Minas Gerais, Brazil." Agricultural Systems 69 (3): 235-257.

Chayanov, A. V. 1966. The Theory of Peasant Economy. Homewood: Richard D. Irwin.

Chayanov, A. V. 1991. The Theory of Peasant Co-Operatives. Columbus: Ohio State University Press.

Comerford, J. C. 2003. Como uma família: sociabilidade, territórios de parentesco e sindicalismo rural. Rio de Janeiro: Relume-Dumará.

da Costa, M. B. B., M. Souza, V. M. Junior, J. J. Comin, and P. E. Lovato. 2017. "Agroecology Development in Brazil Between 1970 and 2015." Agroecology and Sustainable Food Systems 41 (3-4): 276-295.

CPT. 1997. A luta pela terra: A Comissão Pastoral da Terra 20 Anos Depois. São Paulo: Paulus.

CTA-ZM. 2002. Revista 15 anos CTA. Viçosa: CTA.

CTA-ZM. 2005. Sistematização das experiencias com sistemas agroflorestais do CTA/ZM. Viçosa: CTA-ZM.

Cunha, J. S. 2017. "Governo Temer: relaçoes do agronegocio com o capital especulativo financeiro e impactos sobre os camponeses e a legislação agraria." Cadernos do CEAS: Revista Crítica de Humanidades 241: 301-326.

Daskalaki, M. 2017. "Alternative Organizing in Times of Crisis: Resistance Assemblages and SocioSpatial Solidarity." European Urban and Regional Studies 25 (2): 1-16.

Escobar, A. 2010. Territorries of Difference: Place, Movements, Life, Redes. Durham: Duke University Press.

Favareto, A. 2006. "Agricultores, trabalhadores: os trinta anos do novo sindicalismo rural no Brasil." Revista Brasileira de Ciências Sociais 21 (62): 27-44.

Fernandes, B. M. 2008. "Entrando nos territórios do território." In Campesinato e territórios em disputas, edited by E. T. Paulino and J. E. Fabrini, 273-301. São Paulo, Brazil: Expressão Popular.

Fernandes, B. M., C. A. Welch, and E. C. Gonçalves. 2012. Land Governance in Brazil. Framing the Debate Series 2. Rome: ILC.

Firmino, G. C. 2017. “Classes medias e manifestações pro-impeachment na cidade de São Paulo: uma analíse dos movimentos e manifestantes." Politica \& Trabalho 47: 209-227.

Fox, J. 2007. Accountability Politics: Power and Voice in Rural Mexico. Oxford: Oxford University Press. Gramsci, A. 1971. Selections from the Prison Notebooks. New York: International Publishers Co.

Haraway, D. 1993. "The Promises of Monsters: A Regenerative Politics for Inappropriate/d Others." In Cultural Studies, edited by L. Grossberg, C. Nelson, and P. Treichler, 295-337. New York: Routledge.

Holt-Giménez, E., and A. Shattuck. 2011. "Food Crises, Food Regimes and Food Movements: Rumblings of Reform or Tides of Transformation?" Journal of Peasant Studies 38 (1): 109-144. 
Intini, J. M. 2016. O pós golpe na agricultura familiar e na reforma agrária: Extinção de políticas públicas, menos recursos e criminalização dos movimentos sociais. Brasília: Assessoria da Liderança do Partido dos Trabalhadores na Câmara dos Deputados.

Kerkvliet, B. J. T. 2009. "Everyday Politics in Peasant Societies (and Ours)." The Journal of Peasant Studies 36 (1): 227-243.

Laclau, E., and C. Mouffe. 1985. Hegemony and Socialist Strategy: Toward a Radical Democratic Politics. London: Verso.

Loera, R. N. 2006. A espiral das ocupações de terra. São Paulo: Editora Polis \& CERES.

Long, N. 2001. Development Sociology: Actor Perspectives. New York: Routledge.

Malseed, K. 2008. "Where There is No Movement: Local Resistance and the Potential for Solidarity." Journal of Agrarian Change 8 (2-3): 489-514.

Marsden, T. 2012. “Towards a Real Sustainable Agri-Food Security and Food Policy: Beyond Ecological Fallacies?" The Political Quarterly 83 (1): 139-145.

Meszaros, G. 2000. “No Ordinary Revolution: Brazil's Landless Workers' Movement." Race and Class 42 (2): 1-18.

Nyeleni Declaration. 2015. "Declaration of the International Forum for Agroecology, Nyeleni, Mali: 27 February 2015." Development 58 (2-3): 163-168.

O'Brien, K. J. 2013. “Rightful Resistance Revisited." Journal of Peasant Studies 40 (6): 1051-1062.

O'Brien, K. J., and L. Li. 2006. Rightful Resistance in Rural China. New York: Cambridge University Press.

Pahnke, A. 2015. "Institutionalizing Economies of Opposition: Explaining and Evaluating the Success of the MST's Cooperatives and Agroecological Repeasantization." The Journal of Peasant Studies 42 (6): 1087-1107.

Paige, J. 1975. Agrarian Revolution: Social Movements, and Export Agriculture in the Underdeveloped World. New York: The Free Press.

Pimentel, J. 2015. "Impeachment, oposição e autoritarismo: o perfil e demanda dos manifestantes em São Paulo." Em Debate 7 (2): 15-22.

Porto-Gonçalves, C. W. 2006. "De saberes e de territorios: diversidade e emancipacão a partir da experiencia Latino-Americana." Capa 8 (16): 37-52.

Ribot, J. 2013. "Choice, Recognition and the Democracy Effects of Decentralization." In The Imperative of Good Local Governance: Challenges for the Next Decade of Decentralization, edited by J. Öjendal and A. Dellnäs, 93-120. Tokyo: UNU Press.

Rosset, P. M., and M. E. Martinez-Torres. 2012. "Rural Social Movements and Agroecology: Context, Theory and Process." Ecology and Society 17 (3): 17.

Rubin, J. W., and E. Sokoloff-Rubin. 2013. Sustaining Activism: A Brazilian Women's Movement and a Father-Daughter Collaboration. Durham, NC: Duke University Press.

Sabourin, E. 2011. Sociedades e organizacoes camponesas: uma leitura atraves da reciprocidade. Editora da UFRGS: Porto Alegre.

Scheper-Hughes, N. 1992. Death Without Weeping: The Violence of Everyday Life in Brazil. Berkeley: University of California Press.

Schneider, S., and P. A. Niederle. 2010. "Resistance Strategies and Diversification of Rural Livelihoods: The Construction of Autonomy among Brazilian Family Farmers." The Journal of Peasant Studies 37 (2): 379-405.

Scoones, I., M. Edelman, S. M. Borras, R. Hall, W. Wolford, and B. White. 2018. "Emancipatory Rural Politics: Confronting Authoritarian Populism." The Journal of Peasant Studies 45 (1): 1-20.

Scott, J. 1976. The Moral Economy of Peasants: Rebellions and Subsistence in Southeast Asia. New Haven, CT: Yale University Press.

Scott, J. 1987. Weapons of the Weak: Everyday Forms of Peasant Resistance. New Haven, CT: Yale University Press.

Sherwood, S., A. Arce, and M. Paredes, eds. 2017. Food, Agriculture and Social Change: The Everyday Vitality of Latin America. New York: Routledge.

Silva, M. G., M. D. Dias, and S. P. Silva. 2014. "Relações e estratégia de (des)envolvimento rural: politícas públicas, agricultura familiar e dinâmicas locais no município de Espera Feliz (MG)." RESR 52 (2): 229-248. 
de Sousa Santos, B. 2009. "A Non-occidentalist West? Learned Ignorance and Ecology of Knowledges." Theory, Culture \& Society 26 (7-8): 103-125.

Stédile, J. P., and B. M. Fernandes. 1999. Brava gente: A trajetoria do MST e a luta pela terra no Brasil. São Paulo: Editora Fundação Perseu Abramo.

Thomas, M. P., and S. Tufts. 2016. "Austerity, Right Populism, and the Crisis of Labour in Canada." Antipode 48 (1): 212-230.

Toledo, V. M. 1990. “The Ecological Rationality of Peasant Production." In Agroecology and Small-Farm Development, edited by M. Altieri and S. Hecht, 51-58. Boca Raton, FL: CRC Press.

Van den Berg, L., P. Hebinck, and D. Roep. 2018a. "'We Go Back to the Land': Processes of Re-peasantisation in Araponga, Brazil." The Journal of Peasant Studies 45 (3): 653-675.

Van den Berg, L., D. Roep, P. Hebinck, and H. M. Teixeira. 2018b. "Reassembling Nature and Culture: Resourceful Farming in Araponga, Brazil." Journal of Rural Studies 59: 314-322.

Van der Ploeg, J. D. 2007. "Resistance of the Third Kind and the Construction of Sustainability." Paper presented at the conference of the European Society for Rural Sociology, Wageningen, The Netherlands, August 23.

Van der Ploeg, J. D. 2008. The New Peasantries: Struggles for Autonomy and Sustainability in an Era of Empire and Globalisation. New York: Routledge.

Van der Ploeg, J. D. 2017. The Importance of Peasant Agriculture: A Neglected Truth. Farewell address upon retiring as professor of transition processes in Europe at Wageningen University \& Research.

Vergara-Camus, L. 2009. "The MST and the EZLN Struggle for Land: New Forms of Peasant Rebellions." Journal of Agrarian Change 9 (3):365-391.

Vieira, A. O. 2017. "Crise politica e impeachment: uma analíse dos efeitos da cobertura midiatica na deposição de Dilma Rouseff." Perspectivas em dialogo: revista de educação e sociedade 5 (8): 4-26.

Welch, C. A., and S. Sauer. 2015. "Rural Unions and the Struggle for Land in Brazil." The Journal of Peasant Studies 42 (6): 1109-1135.

Wiskerke, J. S. C., and J. D. Van der Ploeg, eds. 2004. Seeds of Transition: Essays on Novelty Production, Niches and Regimes in Agriculture. Assen: Van Gorcum.

Wolf, E. 1975. "On Peasant Rebellions." In Peasant and Peasant Societies, edited by T. Shanin, 264-274. Oxford: Blackwell.

Wolford, W. 2010. This Land is Ours Now: Social Mobilization and the Meanings of Land in Brazil. Durham: Duke University Press.

Woods, M. 2015. "Territorialisation and the Assemblage of Rural Place: Examples from Canada and New Zealand." In Cultural Sustainability and Regional Development: Theories and Practices of Territorialisation, edited by J. Dessein, E. Battaglini, and L. Horlings, 29-43. London: Routledge.

Zimerman, A. 2010. Terra manchada de sangue: conflitos agrários e mortes no campo no Brasil democrático. São Paulo: Humanitas FAPESP.

Zimerman, A. 2016. "A Piece of Land or Peace on the Land: How Much is a Peasant's Life Worth in Brazil?" Journal of Human Security 12 (1): 37-51.

Leonardo van den Berg conducts doctoral research at the Wageningen University and Federal University of Viçosa (UFV). His research analyses sustainable transformation from the perspective of social movements and grassroots alternatives, focusing on the case of agroecology and repeasantisation in Brazil. He is co-founder of Toekomstboeren - the Dutch chapter of La Via Campesina - and of the Dutch Federation of Agroecological farmers. He is also in the coordinating committee of the Dutch Food Sovereignty Platform VoedselAnders and of the Agroecology Collective of the European Coordination of La Via Campesina.

Margriet Goris is a PhD candidate at the Rural Extension group of the Federal University of Viçosa (UFV) and at the Forest and Nature Conservation Policy group of Wageningen University. From August 2016 until August 2018 she lived in Brazil to do action research on the agroecology movement in Brazil. Margriet is an ethnovideographer who works on the interface of film, research and education. She lectures on video for data collection, education and communication, and on agroforestry and agroecology. She is project leader at the Science Shop, a community-based research 
programme of Wageningen UR and she has published on diverse topics including film for social change, African diaspora and agroecology. Margriet Goris is also a board member of the Agroecology Europe association.

Jelle Behagel is Assistant Professor at the Forest and Nature Conservation Policy Group (FNP) of Wageningen University, the Netherlands. His expertise is in the democratic governance of nature, forest discourses, and political practices of forest and nature conservation across the global-local nexus. He currently works on exploring the fantasmatic role of forest and nature in the Anthropocene.

Gerard Verschoor is Assistant Professor in the Sociology of Development and Change Group at Wageningen University and works at the intersections of political ontology, actor-network, and Indigenous perspectivism. His publications have worked through empirical case studies in a range of areas including agricultural intervention, land-use patterns, territoriality, food networks, extractive resources, local knowledge, genetically modified corn, and drink. His current research examines how socio-ecological conflicts are driven by ontological projects, and how to imagine/find common ground between opposing ontological frameworks in situations of skewed environmental governance.

Esther Turnhout is Full Professor at the Forest and Nature Conservation Policy Group of Wageningen University, the Netherlands. Her research program The Politics of Environmental Knowledge includes research into the different roles experts play at the science policy interface, the political implications of policy relevant knowledge, and the participation of citizens in environmental knowledge making, also known as citizen science. Current research focuses on the UN Intergovernmental Platform for Biodiversity and Ecosystem Services (IPBES), human-wildlife conflict and auditing practices in forest management. She has been selected as an expert for IPBES and is currently a lead author of the IPBES Global Assessment.

Maria Izabel Vieira Botelho is former Assistant Professor at the Department of Rural Economics of the Federal University of Viçosa. Her expertise is in the area of Sociology with a focus on Rural Sociology in the following themes: the peasantry and agroecological practices, social identities, livelihood analysis and work. In 2009 she completed a post-doc in Rural Development Sociology at the Wageningen University.

Ivonete da Silva Lopes is Assistant Professor at the Department of Rural Economics of the Federal University of Viçosa. She is also vice chair of the Brazilian Chapter of the Latin Union of Political Economy of Information, Communication and Culture (ULEPICC-BR) and author of the book "TV Brasil e a construção da rede nacional de televisão pública". Her expertise is in: public television, the democratisation of communication, the politics of communication and communication and diversity. 